\title{
RELASI POLITIK PENDIDIKAN DAN POLITIK KEKUASAAN
}

\author{
Maimunah \\ Dosen Manajemen Pendidikan Agama Islam \\ Fakultas Ilmu Agama Islam \\ Universitas Islam Indragiri (FIAI - UNISI) Tembilahan
}

\begin{abstract}
Abstrak
Tulisan ini fokus mengkaji tentang hubungan atau relasi politik pendidikan dan politik kekuasaan, dimana ketika pendidikan sudah menjadi bagian dari kepentingan kekuasaan, maka tujuan dari pendidikanpun akan menjadi tidak jelas, kalau boleh dikatakan tak ubah seperti layangan putus, yang tidak tahu kemana arah angin akan membawanya, jangankan ingin memberi angin segar bagi keberlangsungan suatu bangsa yang carutmarut, pendidikan yang demikian justru hanya akan menjadi agen kepentingan elit politik, yang pada gilirannya tidak mustahil menjadi bom yang siap memporakporandakan bangsa ini. Oleh karenanya, pendidikan sebagai bentuk pelaksanaan konsep kekuasaan Negara perlu dirumuskan peranannya agar terdapat keseimbangan antara kebebasan individu serta keterikatan individu sebagai warga negara dalam wadah persatuan Indonesia. Sebab, proses pendidikan yang sebenarnya adalah proses pembebasan dengan jalan memberikan kepada peserta didik kesadaran akan kemandirian atau memberikan kekuasaan kepadanya untuk menjadi individu.
\end{abstract}

Key words: Politik pendidikan, Politik Kekuasaan

\section{A. Pendahuluan}

Politik pendidikan atau the politics of education dan politik kekuasaan adalah kajian tentang relasi antara proses munculnya berbagai tujuan pendidikan dengan cara - cara penyampaiannya. Kajian ini lebih terfokus pada kekuatan yang menggerakkan perangkat pencapaian tujuan pendidikan dan bagaimana serta kemana perangkat tersebut akan diarahkan. Kajian politik pendidikan terkonsentrasi pada peranan Negara dalam bidang pendidikan, sehingga dapat menjelaskan asumsi dan maksud dari berbagai strategi perubahan pendidikan dalam suatu masyarakat secara lebih baik.Kajian politik pendidikan dapat memberikan pemahaman yang lebih baik tentang kaitan antara berbagai kebutuhan politik Negara dengan isu - isu 
praktis sehari hari di sekolah; tentang kesadaran kelas; tentang berbagai bentuk dominasi dan subordinasi yang sedang dibangun melalui jalur pendidikan.

\section{B. Pembahasan}

a. Relasi Politik dan Pendidikan

Pendidikan dan politik adalah dua elemen penting dalam sistem sosial politik di setiap Negara, baik Negara maju maupun Negara berkembang. Keduanya sering dilihat sebagai bagian - bagian yang terpisah, yang satu sama lain tidak memiliki hubungan apa apa. Padahal, keduanya bahu membahu dalam proses pembentukan karakteristik masyarakat disuatu Negara. Lebih dari itu, keduanya saling menunjang dan saling mengisi lembaga - lembaga dan proses pendidikan berperan penting dalam membentuk perilaku politik masyarakat di Negara tersebut. Ada hubungan erat dan dinamis antara pendidikan dan politik disetiap Negara. Hubungan tersebut adalah realitas empiris yang telah terjadi sejak awal perkembangan peradaban manusia dan menjadi perhatian para ilmuan.

Pendidikan sering dijadikan media dan wadah untuk menanamkan ideology Negara atau tulang yang menopang kerangka politik. Di negara-negara barat kajian tentang hubungan antara pendidikan dan politk dimulai oleh Plato dalam bukunya Republik yang membahas hubungan antara ideologi dan institusi Negara dengan tujuan dan metode pendidikan.

Plato mendemonstrasikan dalam buku tersebut bahwa dalam budaya Helenik, sekolah adalah salah satu aspek kehidupan yang terkait dengan lembanga-lembaga politik. Plato menggambarkan adanya hubungan dinamis antara aktivitas kependidikan dan aktivitas politik. Keduanya sakan dua sisi dari satu koin, tidak mungkin terpisahkan. Analisis Plato tersebut telah meletakkan fundamental bagi kajian hubungan politik dan pendidikan di kalangan generasi ilmuwan generasi berikutnya.

Dalam ungkapan Abernethy dan Coombe (1965 : 287), education and politics are inextricably linked (pendidikan dan politik terikat tanpa bias dipisahkan). Hubungan timbal balik antara politik dan pendidikan dapat terjadi melalui tiga aspek, yaitu pembentukan sikap kelompok (group attitudes), masalah pengangguran (employ- 
ment), dan peranan politik kaum cendikia (the political role of the intelligentsia).

Dalam masyarakat yang lebih maju dan berorientasi teknologi, dan mengadopsi nilai - nilai dan lembaga barat, pola hubungan antara pendidikan dan politik berubah dari pola tradisional ke pola modern. Dibanyak Negara berkembang, dimana pengaruh modernisasi sangat kuat. Jika politik dipahami sebagai praktik kekuatan, kekuasan, dan otoritas dalam masyarakat dan pembuatan keputusan - keputusan otoritatif tentnag alokasi sumber daya dan nilai-nilai sosial (Harman, 1974 : 9), maka jelaslah bahwa pendidikan tidak lain adalah sebuah bisnis politik.

Hal tersebut menegaskan bahwa pendidikan dan politik adalah dua hal yang berhubungan erat dan saling mempengaruhi. Dengan kata lain, berbagai aspek pendidikan senantiasa mengandung unsur - unsur politik. Begitu juga sebaliknya, setiap aktivitas politik ada kaitannya dengan aspek - aspek kependidikan.

Secara tegas, pendidikan adalah media mencerdaskan kehidupan bangsa dan membawa bangsa ini pada era aufklarung (pencerahan). Pendidikan bertujuan untuk membangun tatanan bangsa yang berbalut dengan nilai - nilai kepintaran, kepekaan dan kepedulian terhadap kehidupan berbangsa dan bernegara.

Pendidikan merupakan tonggak kuat untuk mengentaskan kemiskinan pengetahuan, menyelesaikan persoalan kebodohan dan menuntaskan segala permasalahan bangsa yang selama ini terjadi. Sangat jelas, peran pendidikan signifikan dan sentral sebab ia memberikan pembukaan dan perluasaan pengetahuan sehingga bangsa ini betul - betul melek terhadap kehidupan berbangsa dan bernegara. Pendidikan dihadirkan untuk mengantarkan bangsa ini menjadi bangsa yang beradab dan berbudaya. Ia dilahirkan untuk memperbaiki segala kebobrokan yang sudah menggumpal di segala sendi kehidupan di bangsa ini.

b. Relasi Politik Pendidikan dan Pembentukan Karakter Bangsa

Menurut Mohammad Daud Ali dalam bukunya Pendidikan Agama Islam (2000) disebutkan: Politik itu berasal dari bahan Latin atau bahasa Yunani Politicos yang berarti sesuatu yang berhubungan 
dengan warga Negara atau dengan warga kota. ${ }^{1}$ Menurut Kamus Besar Bahasa Indonesia (KBBI), pengertian politik sebagaimana ditulis : (1) pengetahuan tentang ketatanegaraan atau kenegaraan, yaitu mengenai system pemerintahan, dasar - dasar pemerintahan dan sebagainya; (2) segala urusan dan tindakan, kebijaksanaan, siasat dan sebagainya tentang pemerintahan ataupun terhadap Negara lain; atau (3) kebijakan, cara bertindak di dalam menghadapi suatu masalah tertentu. ${ }^{2}$ Secara tegas, politik adalah suatu cara atau metode memengaruhi orang atau pihak lain untuk mencapai tujuan kelompok. Dalam UU Sistem Pendidikan Nasional (Sisdiknas) pasal 1 UU No. 20 Tahun 2003 disebutkan bahwa pendidikan adalah usaha sadar dan terencana untuk mendidik secara aktif mengembangkan potensi pembelajaran agar peserta memiliki kekuatan spiritual keagamaan, pengendalian diri, kepribadian, kecerdasan, akhlaq serta keterampilan yang di perlukan dirinya, masyarakat, bangsa dan Negara. ${ }^{3}$

Disebutkan pula dalam pasal di atas bahwa pendidikan nasional merupakan pendidikan yang berlandaskan pancasila dan undang-undang dasar Republik Indonesia tahun 1945 yang berakar pada nilai - nilai agama, kebudayaan nasional Indonesia dan tanggap terhadap perubahan zaman. Dalam konteks ini, politik pendidikan nasional dimaksudkan sebagai pendekatan atau metode yang didasarkan pada kebudayaan bangsa Indonesia guna memengaruhi pihak-pihak tertentu dalam rangka mencapai tujuan pendidikan nasional. ${ }^{4}$ Oleh karenanya, sebelum lebih jauh membincangkan pendidikan, maka akan lebih diperjelas dulu apakah itu politik pendidikan. Menurut Ki Supriyoko, ada lima definisi mengenai politik pendidikan. Pertama, ia adalah metode memengaruhi pihak lain untuk mencapai tujuan pendidikan.

Kedua, ia lebih berorientasi pada bagaimana tujuan pendidikan

1 Ali Mahmudi Amnur (ed). Konfigurasi Politik Pendidikan Nasional. (Yogyakarta: Pustaka Fahima, 2007). Hlm. 3.

2 Lihat Kamus Besar Bahasa Indonesia (KKBI). (Jakarta: Balai Pustaka, 2002),Hlm. 348

3 UU Sisdiknas No. 20 Tahun 2003 (Bandung: Fokusmedia,2003). Hlm 3.

4 Ali Mahmud Amnur (ed). Konfigurasi Politik Pendidikan Nasional (Yogyakarta: Pustaka Fahima,2007). Hlm. 4 


\section{$124 \frac{\text { Jurnal AL-AFKAR }}{\text { Vol. II, No. II, Oktober } 2013}$}

dapat dicapai. Ketiga, ia berbicara bagaimana metode untuk mencapai tujuan pendidikan, misalnya tentang anggaran pendidikan, kebijakan pemerintah, partisipasi masyarakat dan sebagainya. Keempat, ia berbicara mengenai sejauh mana pencapaian pendidikan sebagai pembentuk manusia Indonesia yang berkualitas, penyangga ekonomi nasional, pembentuk bangsa yang berkarakter dan sebagainya. ${ }^{5}$ Dengan demikian, politik pendidikan dimaknai sebagai sebuah endapan politik Negara, penjabaran dari tradisi bangsa dan nilainilai serta sistem konsepsi rakyat mengenai bentuk Negara dalam system pendidikan. ${ }^{6}$ Sementara secara umum mengutip pendapat Kneller, tatanan politik suatu bangsa dan sistem pendidikan terjadi mutually reinforching. ${ }^{7}$ Yang pasti, politik pendidikan pembangunan bangsa yang lebih baik ke depannya.

Ia menjadi panduan utama dalam perjalanan pendidikan kebangsaan. Dengan adanya politik pendidikan yang jelas, maka konsep pendidikan yang akan dibentuk dan di capai pun akan berada dalam bangunan konsep yang tepat, kuat dan kokoh. Mencerahkan. Pendidikan pun mampu melahirkan produk-produk pendidikan yang berkualitas dan dapat dipertanggung jawabkan baik secara intelektual maupun sosial. Bagi pemerintah selaku politik pendidikan yang terarah, ini meniscayakan adanya kebijakan-kebijakan pendidikan yang mencerahkan dan memberadabkan. Namun apabila saat ini, masih banyak kebijakan pendidikan yang proyek komersialisasi tertentu, ini disebabkan oleh politik pendidikan yang dijalankan oleh pemerintah lebih cenderung memihak kepada golongan tertentu. Definisi politik pendidikan yang terbuka tidak diinternalisasi dalam setiap ruh kebijakan pendidikan yang akan di lahirkan.

Menurut Benny Susetyo, politik pendidikan kerdil dan sempit yang merupakan hasil reduksionisme telah mengubur nilai hakiki politik pendidikan sejatinya. ${ }^{8}$ Yang jelas, politik pendidikan yang

5 Ali Mahmud Amnur (ed). Konfigurasi Politik Pendidikan Nasional (Yogyakarta: Pustaka Fahima,2007). Hlm 5.

6 Lihat Kartini Kartono. Tinjauan Politik Mengenai Sistem Pendidikan Nasional (Bandung : Mandor Maju, 1997) Hlm. 28

7 George F. Kneller. Politic Ideologies dalam George F. Kneller (ed). Foundations of Education. (New York : John Wiley dan Sons) Hlm. 128

8 Benny Susetyo. Politik Pendidikan Penguasa (Yogyakarta : LKiS, 2005) 
terbuka dan mencerahkan akan bisa dijalankan dengan sedemikian rupa apabila pembentukan karakter bangsa mulai dari elit lapis paling atas hingga paling bawah betul - betul dikerjakan dengan sedemikian tgas dan kongkrit.

Pertanyaannya adalah apakah pembentukan karakter bangsa itu sendiri? Sebelum berbicara pembentukan karakter bangsa, ada baiknya berbicara karakter terlebih dahulu. Dalam Kamus Besar Bahasa Indonesia (KBBI), karakter itu berarti sifat-sifat kejiwaan, akhlak atau budi pekerti yang membedakan seseorang dari yang lain. Berkarakter berarti memiliki tabiat, memiliki kepribadian, atau berwatak. ${ }^{9}$ Watak itu adalah sifat batin manusia yang mempengaruhi segenap pikiran dan tingkah laku. ${ }^{10}$ Para pendidik dan psikolog yang terlibat dan melibatkan diri dalam pendidikan karakter memberikan definisi karakter sebagai sifat-sifat suatu kepribadian yang tunduk pada sanksi-sanksi moral dari masyarakat.

Namun Soemarno Sudarsono menggambarkan perbedaan pengertian antara identitas, jati diri, karakter dan aspek-aspek kepribadian manusia. Identitas itu lebih menunjukkan penampilan fisik : Jati diri merupakan sifat dasar hakiki, asli berasal dari Tuhan; karakter itu merupakan watak yang merupakan pengembangan jati diri manusia. Karakter itu merupakan aspek kepribadian manusia, selain intelektual, temperamen dan keterampilan. ${ }^{11}$ Erich Fromm seorang filsuf hebat berpendapat bahwa karakter adalah alasan-alasan, motivasi, yang di sadari ataupun tidak, mengapa seseorang melakukan tindakan-tindakan tertentu (the behavioral traits) dengan sifat - sifat karakter (the character traitsi). Erich Fromm menyampaikan bahwa hakikat karakter harus dicari dalam corak hubungan seseorang dengan lingkungannya, benda (asimilasi) maupun manusia (sosialisasi). Produktif atau tidak. ${ }^{12}$ Dengan dimikian, karakter pribadi sangat me-

9 Tim Penyusun Kamus Pusat Pembinaan dan Pengembangan Bahasa. Kamus Besar Bahasa Indonesia. Ed.2, Cet.3. (Jakarta: Balai Pustaka, 1994). Hlm. 445.

10 Tim Penyusun Kamus Pusat Pembinaan dan Pengembangan Bahasa. Kamus Besar .... Hl. 1126.

11 Soemarno Sudarsono. Character Building Membentuk Watak (Jakarta: PT Elex Media Komputindo, 2002).

12 Erich Fromm. Man for Himself. An Inqury into Psychology of Ethics (New York: Holt, Rinebart and Wisdom, 1964). Hlm 59. Dikatakan produktif apabila se- 


\section{$126 \frac{\text { Jurnal AL-AFKAR }}{\text { Vol. II, No. II, Oktober } 2013}$}

nentukan karakter sebuah bangsa, termasuk bangsa Indonesia.

Sejarah perjalanan bangsa ini membuktikan bahwa negeri ini memiliki pengalaman politik yang sangat padat. Reformasi yang digelorakan sejak mei 2008 menimbulkan ekses yang politik di samping vandalisme, brutalisme, anarkisme dan kekerasan fisik lainnya (penampilan bawah). Juga KKN dan penyalahgunaan wewenang dan kekuasaan (penampilan atas). Dengan demikian, Indonesia justru menghadapi dua masalah bangsa dan masalah penting yang berkaitan dengan pembangunan karakter bangsa. Yang jelas, karakter bangsa berkaitan erat secara timbal dengan etika berbangsa. Hal ini disinyalir bahwa etika berbangsa merupakan perasaan dan kecendrungan hati individu atau kelompok dalam berprilaku di masyarakat dalam bangsa telah melakukan proses berpendidikan secara tegas tetap menjadi media terpenting dan maha utama guna membangun potensi kemanusiaan yang berkarakter kemanusiaan dan berperilaku santun antar sesama. Pendidikan dapat mengembangkan jati diri kemanusiaan yang berdaulat dan bermartabat, bahkan bisa melahirkan masyarakat yang beradab dan berbudaya ketika pendidikan betul - betul menjadi dan dijadikan tulang punggung sebuah perjalanan bangsa ke depannya.

Oleh karennya, bila dikaitkan dengan pendidikan sebagai sebuah pembentukan karakter bangsa, maka hal demikian tidak akan terlepas dari nilai-nilai kesatuan antar pribadi ke pribadi yang kemudian menyatu serta melebur menjadi sebuah kelompok baik maupun besar di kemudian hari. Dengan kata lain yang lebih tegas, pendidikan berperan dalam membangun suku, agama, budaya dan lain seterusnya. Berkehidupan dan membangun kehidupan antar sesama solid dan konstruktif kemudian dapat dipahami sebagai sebuah kehidupan berbangsa yang siap akan mengganggunya. Menurut Soemarno Sudarsono, ada beberapa hal penting yang dapat dijadikan pijakan penting dalam membentuk sebuah karakter bangsa;(1) kejujuran, 2) keterbukaan, 3) keberanian mengambil resiko, 4) bertanggung jawab, 5) memenuhi komitmen dan 6) kemampuan berbagi.

seorang mampu merealisasikan dan memanfaatkan potensi-potensi dan dayadaya fisiknya (kesadaran diri, imajinasi dan cinta kasih) secara bebas tanpa tergantung pada orang lain dalam melaksanakan proses asimilasi dan sosialisasi. (Yogyakarta: Pustaka Fahima, 2007) Hlm. 75 
Sedangkan Benjamin S. Bloom mengembangkan teori yang dikenal dengan "Teori Tiga Domain"; Kognitif, Afektif dan Psikomotorik. ${ }^{13}$ Termasuk pula, tujuan pendidikan Islam juga dapat digunakan sebagai dasar guna membangun karakter bangsa : Takwa, Ilmu dan Teknologi dan Akhlak. Hal ini terkait dengan tiga inti ajaran islam, yakni aqidah dengan memperkokoh keyakinan; syariah dengan melakukan penegakkan atauran: dan dengan melakukan perbaikan perilaku. ${ }^{14}$ Oleh karenanya, dari beberapa teori tersebut dapat disampaikan bahwa karakter bangsa sesungguhnya dapat dilakukan melalui perilaku yang baik di tengah masyarakat atau mencontoh para perilaku masyarakat sebelumnya yang memiliki perilaku baik untuk kemudian bisa diterapkan dalam kehidupan sehari. Menurut islam, hal tersebut uswatun hasanah.

Djohar berpendapat bahwa sah-sah saja sebuah bangsa memiliki konsep pendidikan ideal sebagaimana yang dielaborasikan di atas sebab itulah yang harus digagas. Sebab tanpa sebuah konsep cerdas dan cemerlang, maka cita-cita bangsa guna melahirkan bangsa yang berkerakter dengan segala warna-warninya tidak akan bisa direalisasikan dengan sedemikian rupa dan nyata. Justru hal tersebut ibarat panggung jauh dari api.

Akan tetapi yang menjadi pertanyaan dan persoalan adalah selama ini konsep agung yang maha agung tinggal sebuah konsep semata sebab hanya menjadi dekorasi belaka, ditumpuk dalam tulisan - tulisan kertas akan tetapi tidak diamalkan secara kongkrit dan nyata. Sehingga sangat mustahil pula apabila karakter bangsa yang baik, santun, ramah dan lain seterusnya muncul ke permukaan sebagai sebuah cerminan bangsa yang berkarakter. Bangsa Indonesia di dunia manapun sangat dikenal dengan konsep Pancasilanya yang tersebut santun, ramah dan lain seterusnya. Namun hal tersebut hanyalah sebuah slogan semata yang tidak menjadi sebuah kenyataan. Sebut saja, berbagai konflik horizontal yang melanda negeri ini

13 Noeng Munghajir, mengkritik ranah psikomotorik karena dilakukan dengan tidak sadar. Karenanya ranah amaliyah (muamalah) dianggap lebih tepat dengan alasan dilakukan alasan dilakukan secara sadar. Hlm 50.

14 Salmah Fa'atin, "Pendidikan Sebagai Pembentuk Bangsa Berkarakter" dalam konfigurasi Politik Pendidikan Nasional. Editor: Ali Mahmudi Amnur. (Yogyakarta: Pustaka Fahima, 2007). Hlm.78 


\section{$128 \frac{\text { Jurnal AL-AFKAR }}{\text { Vol. II, No. II, Oktober } 2013}$}

baik atas nama suku, agama, ras dan adat sangat marak terjadi. Pendidikan sebagai sebuah alat membangun karakter yang diwujudkan dalam perilaku dan sikap hanyalah sebuah isapan jempol belaka.ini masih belum berbicara tingkat arogansi para elit lapis atas terhadap warganya sebagai masyarakat yang harus dan seharusnya dilindungi. Simak saja, beberapa kebijakan baik dalam bidang ekonomi, politik, pendidikan dan lain seterusnya menunjukkan sebuah potret para elit lapis atas yang tidak berkarakter pemimpin. Sebab pemimpin sejatinya harus melayani bukan menjadikan masyarakatnya susah.

Lebih jauh, berdasarkan evaluasi yang dilakukan Djohar, selama ini kian jelas bahwa pendidikan tidak berhasil melakukan pendewasaan diri terhadap anak didiknya. Lembaga pendidikan di Pertiwi ini gagal melakukan penataan pranata sosial yang mampu membangun karakter bangsa Indonesia sesuai dengan nilai - nilai normatif kebangsaan yang diidealkan. Justru yang terbangun saat ini adalah perilaku elit negeri yang bertolak belakang dengan nilai sosial dan kehendak masyarakat. ${ }^{15}$ Sehingga sangat wajar apabila pembangunan kualitas manusia Indonesia berdasarkan hasil penelitian United $\mathrm{Na}$ tion Development Program (UNDP) tahun 2000, kualitas pendidikan Indonesia dalam Indeks pembangunan kemanusiaan (human development index) berada pada peringkat 109 sementara Singapura, Malaysia, Filipina dan Thailand berada di angka ke-24 hingga 34. Secara tegas, potret jembloknya pendidikan di negeri ini sangat mustahil mampu membangun karakter bangsa yang diharapkan berama sebab segala infratruktur dan suprastrukturnya sudah buruk.

Oleh karenanya, membentuk karakter bangsa merupakan sebuah keniscayaan yang perlu dilakukan apabila bangsa ini berkehendak menjadi bangsa yang beradab dan berbudaya. Pendidikan sebagai sebuah langkah tegas pembentuk karakter perlu dan wajib dilakukan. Menurut Salmah Fa'atin yang dikutip dari beberapa peneliti menyatakan bahwa pendidikan ada pada dua kepentingan yang sama kuat; kepentingan politik kekuasaan dan kepentingan golongan. Jika demikian, sebenarnya dunia pendidikan di masa mendatang bukan lahan paling baik untuk membangun karakter bangsa. Bahkan pendidikan bisa menjadi lahan paling subur menumbuhkan manusia

15 Djohar. Pendidikan Strategik Alternatif untuk Pendidikan Masa Depan (Yogyakarta: LESFI, 2003). Hlm 4-10. 
- manusia bermental politisi, manipulatif dan mungkin pendendam yang tidak memedulikan masalah bersama tetapi lebih Concern dengan kelompoknya. Sehingga pendidikan kita tidak lagi sesuai dengan amanat pembukaan UUD 1945 sebagai proses pencerdasan bangsa yang majemuk. ${ }^{16}$ Menurut Djohar, Pendidikan yang kontekstual atau transformative, (2) pendidikan yang menumbuhkan kesadaran secara vertikal maupun horizontal, dan (3) menempatkan institusi pendidikan di tengah-tengah pergaulan masyarakat luas baik local maupun global, serta (4) memiliki muatan pendidikan yang seimbang antara kepentingan dan pengalaman. ${ }^{17}$

Apabila dijelaskan lebih jauh, maka pendidikan yang kontekstual atau transformatif adalah pendidikan yang menumbuhkan diri untuk mampu melakukan adaptasi diri terhadap lingkungan. Sebuah pendidikan yang menekankan proses demokratis. Tidak terjadi saling hujat menghujat antara satu kelompok dengan kelompok lain. Perbedaan dan keberadaan golongan menjadi sebuah perekat kebersamaan untuk membangun bangsa yang lebih baik dalam sebuah komunitas global yang bernaung di bawah NKRI. Dalam pendidikan konteksual, penekanannya adalah bagaimana setiap masyarakat bisa dinamis dan konstruktif dalam membangun dialog antar sesama. Mereka saling membangun persaudaraan ketimbang permusuhan antar golongan.

Sedangkan pendidikan trans-formatif adalah pendidikan yang mampu merubah karakter masyarakat yang selama ini tertutup menjadi terbuka. Mereka menerima segala perbedaan dan keberbedaan yang ada di tengah kehidupannya yang sangat majemuk. Pendidikan transformatif adalah sebuah konsep pendidikan yang berupaya sekuat tenaga untuk menciptakan nalar berpikir masyarakat yang peduli terhadap realitas masyarakat. Apabila sebuah kelompok masyarakat tertentu sedang berada dalam persoalan sosial, sebut saja kemiskinan, maka akan segera mendapatkan pertolongan dengan sedemikian cepat dan tangkas. Secara tegas, pendidikan transformatif memiliki kerangka berpikir yang menekankan pola berpikir yang tegas dan berani terhadap perkembangan sosial kemasyarakatan yang harus segera mendapatkan respon baik, positif dan kosntruktif.

16 Djohar. Pendidikan Strategik, ... hlm 123.

17 Djohar, Pendidikan Strategik, ... hlm 121. 


\section{$130 \frac{\text { Jurnal AL-AFKAR }}{\text { Vol. II, No. II, Oktober } 2013}$}

Sedangkan pendidikan untuk menumbuhkan kesadaran vertikal maupun horizontal bertujuan untuk melahirkan kesadaran sebuah bangsa. Diakui maupun tidak, negeri ini pasti ada yang dipimpin maupun yang memimpin. Masyarakat yang dipimpin harus patuh terhadap segala aturan yang ada, jangan membuat keonaran tertentu yang menyebabkan kekisruhan sosial. Sebagai warga Negara yang baik, harus bisa menjalani hidup secara tertib dsan damai. Sebaliknya yang memimpin pun harus bersikap demokratis, mau dikritik dan bisa diberi masukan. Yang memimpin tidak berpikir sempit dan kerdil, justru berpandangan terbuka dan meluas sehingga ini melahirkan sebuah pandangan yang baik terhadap masyarakatnya. Ini pun dapat membawa sebuah kebijakan yang dilahirkan pun tidak diskriminatif. Yang memimpin harus mampu merangkul semua kelompok masyarakat yang berbeda baik suku, ras, agama, dan lain seterusnya.

Sementara menempatkan lembaga pendidikan baik lokal maupun global adalah ia mampu mengikuti perkembangan zaman, adanya berbagai perubahan yang terjadi di lingkungan sekitar baik dalam negeri maupun luar negeri selalu diikuti sehingga ini melahirkan lembaga pendidikan yang berkualitas dan baik. Sedangkan pendidikan harus memuatkan nilai-nilai kepentingan dan pengalaman, ini dipahami bahwa pendidikan tidak serta merta bersifat teoritis akan tetapi pula praksis. Pendidikan benar-benar mencerminkan sebuah proses berpendidikan yang menyeluruh, mengglobal, holistik dan mendalam. Pendidikan dalam konteks demikian dapat membentuk sebuah karakter bangsa yang betul-betul menandakan sebuah keberpahaman kondisi bangsa secara integral dalam segala bidang kehidupan. Oleh sebab itu, ketika hal demikian dapat dilakoni dengan sedemikian baik dan tegas, sangat niscaya karakter bangsa yang diidealkan bersama bisa terealisasi dengan sedemikian kongkrit dan praksis.

Oleh sebab itu, seorang pedagog asal Jerman F.W Foerster (1869-1966) yang menekankan dimensi etis spiritual dalam proses pembentukan pribadi kemudian mengatakan bahwa pendidikan karakter merupakan langkah guna membentuk karakter yang selanjutnya termanifestasikan dalam kesatuan ensensial subjek dengan prilaku dan sikap hidup setiap pribadi manusia. Pejabat publik tentu 
sangat memerlukan pendidikan karakter sebagai bagian inheren dalam pembentukan jati diri yang berkarakter.

\section{c. Kontrol Negara terhadap Pendidikan}

Sebagai suatu proses yang banyak menentukan corak dan kualitas kehidupan individu dan masyarakat, tidak mengherankan apabila semua pihak memandang pendidikan sebagai wilayah strategis bagi kehidupan manusia sehingga program - program dan proses yang ada di dalamnya dapat dirancang, diatur, dan diarahkan sedemikian rupa untuk mendapatkan output yang diinginkan. Ini yang menjadi salah satu alasan mengapa suatu Negara sangat pedulu dan menyediakan anggaran dalam jumlah yang besar untuk bidang pendidikan. Semua itu dilakukan dalam rangka membangun suatu sistem pendidikan yang memiliki karakteristik, kualitas, arah, dan output yang diinginkan. Untuk memastikan terwujudnya keinginan tersebut, banyak Negara yang menerapkan control yang sangat ketat terhadap program-program pendidikan, baik yang diselenggarakan sendiri oleh Negara maupun yang diselenggarakan oleh masyarakat.

Pemerintah adalah bagian dari Negara yang paling kasat mata dan dapat juga menjadi bagian paling penting dan paling aktif dari Negara, tetapi pemerintah bukanlah keseluruhan dari Negara. Negara terdiri dari berbagai institusi yang masing masing memiliki fungsi dan peran tersendiri dalam tatanan kehidupan kenegaraan.

Menurut Dale (1989: 39 - 43), kontrol Negara terhadap pendidikan umunnya dilakukan melalui empat cara. Pertama, sistem pendidkan diatur secara legal. Kedua, system pendidikan dijalankan sebagai birokrasi, menekankan ketaatan pada aturan dan objektivitas. Ketiga, penerapan wajib pendidikan (compulsory education). Keempat, reproduksi politik dan ekonomi yang berlangsung di sekolah berlangsung dalam konteks tertentu. Dale (1989 : 59) menambahkan bahwa perangkat Negara dalam bidang pendidikan, sepeti sekolah dan administrasi pendidikan memiliki efek tersendiri terhadap pola, proses, dan praktik pendidikan.

d. Sebuah analisa

Menurut Romo Mangun Wijaya, pendidikan adalah proses awal dalam usaha menumbuhkan kesadaran sosial pada setiap ma- 


\section{$132 \frac{\text { Jurnal AL-AFKAR }}{\text { Vol. II, No. II, Oktober } 2013}$}

nusia sebagai pelaku sejarah. Kesadaran sosial hanya akan bisa tercapai apabila seseorang telah berhasil membaca realitas perantaraan dunia di sekitar mereka. Sebagai usaha untuk menambahkan kesadaran sosial, maka perlu adanya perangkat analisis yang bersumber dari kebebasan berpikir dari masing - masing individu, yang pada akhirnya memberikan daya nalar yang kritis terhadap perkembangan sosial yang ada. ${ }^{18}$ Sementara Jean Piaget mendefenisikan pendidikan sebagai penghubung dua sisi," di satu sisi, individu yang sedang tumbuh (dan) disisi lain, nilai sosial, intelektual dan moral yang menjadi tanggung jawab pendidikan untuk mendorong individual tersebut. Individu berkembang sejak lahir dan terus berkembang. ${ }^{19}$ Merujuk dari dua pemikir tersebut, pendidikan sesungguhnya berupaya guna membangun kesadaran sosial kemasyarakatan yang tinggi terhadap masyarakat ataupun anak didik supaya mereka menjadi peka dan peduli terhadap realitas sosial. Pendidikan mengarahkan pada terbangunnya paradigma berpikir yang tidak jauh dari realitas sosial namun mampu bersentuhan secara kongkrit dan riil dengan sesuatu yang sedang terjadi dalam persoalan sosial kemasyarakatan.

Sebut saja, bila dan banyak anak miskin, terlantar dan tidak mampu bersekolah karena pertimbangan financial. Maka, yang sudah berpendidikan dan memiliki kemampuan guna memberikan fasilitas pendidikan secara gratis,mereka pun harus bergerak untuk melakukan hal tersebut. Yang jelas, pendidikan itu menumbuhkan nalar kritisisme sosial. Menurut ahli sosiologi pendidikan, terdapat relasi resiprokal (timbal balik) antara dunia pendidikian dengan kondisi sosial masyarakat. Relasi ini bermakna bahwa apa yang berlangsung dalam dunia pendidikan, merupakan gambaran dari kondisi yang sesungguhnya di dalam kehidupan masyarakat yang kompleks. Demikian juga peradaban dan lain sejenisnya tercermin dalam kondisi dunia pendidikannya. Oleh karenanya, majunya dunia pendidikan dapat dijadikan cermin majunya masyarakat dan dunia pendidikan yang amburadul juga dapat menjadi cermin terhadap

18 Benny Susetyo. Politik Pendidikan Penguasa. (Yogyakarta: LKiS, 2005). Hlm.145146

19 Joy A. Palmer (ed). 50 Pemikir Pendidikan.Terj. (Yogyakarta: Jendela 2003). Hlm. 75 
kondisi masyarakatnya yang juga penuh persoalan. ${ }^{20}$

Sementara Ary H. Gunawan berpendapat bahwa pendidikan dapat diartikan sebagai proses sosialisasi, yaiut sosialisasi nilai, pengetahuan, sikap dan keterampilan. ${ }^{21}$ Oleh karenanya, pendidikan senyatanya harus mampu menjawab persoalan - persoalan yang berada di tengah masyarakat. Melakukan analisa kritis dalam pendidikan merupakan sebuah kemestian yang harus dilakoni dengan sedemikian rupa. Pendidikan bukan hanya mencetak masyarakat yang cerdas secara intelektual namun juga mampu merasakan segala keluh kesah yang berada di sekitarnya. Masyarakat terdidik mampu berbaur dan membaurkan diri bersama kelompok - kelompok masyarakat lain yang sedang membutuhkan pertolongan untuk dicerdaskan. Dalam konteks ini, pembauran masyarakat terdidik tidaklah pasif melainkan aktif partisipatoris. Dalam konteks pertama, masyarakat terdidik hanya mampu mengamati segala persoalan yang sedang terjadi di tengah masyarakat, seperti kemiskinan, pengangguran, kebodohan dan sederetan persoalan lainnya.

Akan tetapi kendatipun sudah melakukan pembacaan dengan sedemikian rupa, hal tersebut tidak dilakukan dengan langkah langkah kongkrit dan praktis terkait apa saja yang harus dilakukan. Sehingga ini menjadikan masyarakat terdidik menjadi mandul, sedang hidup di menara gading. Ketika sedang terjadi kesusahan di tengah masyarakat, mereka sangat apatis dan anti pati sehingga tidak muncul satu gerakan dan pergerakan apapun bagaimana menuntaskan persoalan - persoalan yang sedang melanda mereka. Alih - alih dalam konteks pendidikan pasif hanya mampu memberikan konsep berpendidikan yang mencerdaskan namun tidak mampu mencetak berpikir yang berkehendak tinggi bagi pembangunan tatanan kemasyarakatan yang baik, dinamis dan terdidik di lingkungan sekitar. Akan tetapi hal tersebut sangat berbeda jauh dengan pendidikan aktif partisipatif yang sangat berperan bagi terbangunnya perubahan

20 Ngainum Naim \& Achmad Sauqi. Pendidikan Multikultural, Konsep dan Aplikasi ( Yogyakarta:Ar-Ruzz. 2008). Hlm . 13.

21 Ary H. Gunawan. Sosiologi Pendidikan, Suatu Analisa Sosiologi tentang Berbagai Problem Pendidikan., (Jakarta: Rineka Cipta, 2000). Hlm. 54-55. Ngainum Naim \& Achmad Sauqi. Pendidikan Multikultural, Konsep dan Aplikasi (Yogyakarta: Ar-Ruzz, 2008). Hlm. 13-14 


\section{$134 \frac{\text { Jurnal AL-AFKAR }}{\text { Vol. II, No. II, Oktober } 2013}$}

sosial. Dalam model sedemikian itu, masyarakat yang berpendidikan tidak hanya memiliki nalar intelektual sangat tinggi namun juga dilengkapi dengan kekuatan emosi dan sosial yang luar biasa dalam menjawab persoalan kemasyarakatan.

Apabila dua konsep berpendidikan tersebut dihubungkan dengan konsepnya Benjamin S. Bloom, yakni kognisi, afeksi dan psikomotorik, maka hampir sama, persamaanya terletak pada kognisi dan psikomotrik. Oleh karenanya, menjadi sebuah tuntutan dan kewajiban apabila pendidikan jangan semata melahirkan output yang asing terhadap kondisi lingkungan sekitanya. Pendidikan harus mampu mencakup sosial. Kecerdasan intelektual maupun kecerdasan sosial. Kecerdasan intelektual adalah melahirkan out - put pendidikan yang betul - betul memiliki kapasitas keilmuan sangat tinggi, bisa di pertanggung jawab kan secara akademis dan ilmiah, tidak hanya selesai berpendidikan namun tong kosong nyaring bunyinya. Kecerdasan intelektual adalah menumbuhkan kekuatan nalar berpikir yang sarat dengan kandungan - kandungan keilmiahan sehingga ketika melakukan proses berpikir dan pemikiran, hasil pemikirannya sangat dipercaya oleh publik sebagai konsumen pendidikan.

Masyarakat terdidik bisa diidentifikasi seberapa besar dan hebat kemampuan kecerdasan intelektualnya. Akan tetapi hal tersebut harus di topang dengan kecerdasan sosial. Dengan kata lain, ia merupakan penyelamat kehidupan masyarakat ketika sedang dihadapkan pada berbagai permasalahan yang ada. Kecerdasan sosial dari seorang masyarakat terdidik mereka bisa mengenal setiap persoalan yang ada di tengah publik, memberikan tawaran kongkrit terhadap persoalan masyarakat yang sedang berkecamuk.

\section{Penutup}

Pendidikan dan politik adalah dua relasi erat dan saling mempengaruhi. Dengan kata lain, berbagai aspek pendidikan senantiasa mengandung unsur - unsur politik. Begitu juga sebaliknya, setiap aktivitas politik ada kaitannya dengan aspek - aspek kependidikan.

Kontrol Negara terhadap pendidikan umunnya dilakukan melalui empat cara. Pertama, sistem pendidkan diatur secara legal. Kedua, sistem pendidikan dijalankan sebagai birokrasi, menekankan 
ketaatan pada aturan dan objektivitas. Ketiga, penerapan wajib pendidikan (compulsory education). Keempat, reproduksi politik dan ekonomi yang berlangsung disekolah berlangsung dalam konteks tertentu.

\section{Daftar Pusataka}

Ali Mahmud Amnur (ed). Konfigurasi Politik Pendidikan Nasional. Yogyakarta: Pustaka Fahima, 2007.

Ali Mahmudi Amnur (ed). Konfigurasi Politik Pendidikan Nasional. Yogyakarta: Pustaka Fahima, 2007

Ary H. Gunawan. Sosiologi Pendidikan, Suatu Analisa Sosiologi tentang Berbagai Problem Pendidikan. Jakarta: Rineka Cipta, 2000

Benny Susetyo. Politik Pendidikan Penguasa. Yogyakarta : LKiS, 2005

Benny Susetyo. Politik Pendidikan Penguasa. Yogyakarta: LKiS, 2005

Djohar. Pendidikan Strategik Alternatif untuk Pendidikan Masa Depan. Yogyakarta: LESFI, 2003

Erich Fromm. Man for Himself. An Inqury into Psychology of Ethics New York: Holt, Rinebart and Wisdom, 1964

George F. Kneller. Politic Ideologies dalam George F. Kneller (ed). Foundations of Education. (New York : John Wiley dan Sons

Joy A. Palmer (ed). 50 Pemikir Pendidikan. Terj. Yogyakarta: Jendela 2003

Kamus Besar Bahasa Indonesia (KKBI). Jakarta: Balai Pustaka, 2002

Kartini Kartono. Tinjauan Politik Mengenai Sistem Pendidikan nasional. Bandung : Mandor Maju, 1997

li Mahmud Amnur (ed). Konfigurasi Politik Pendidikan Nasional. Yogyakarta: Pustaka Fahima,2007

Ngainum Naim \& Achmad Sauqi. Pendidikan Multikultural, Konsep dan Aplikasi. Yogyakarta:Ar-Ruzz. 2008

Ngainum Naim \& Achmad Sauqi. Pendidikan Multikultural, Konsep dan Aplikasi. Yogyakarta: Ar-Ruzz, 2008

Salmah Fa'atin, "Pendidikan Sebagai Pembentuk Bangsa Berkarakter" dalam konfigurasi Politik Pendidikan Nasional. Editor: Ali Mahmudi Amnur. Yogyakarta: Pustaka Fahima, 2007

Soemarno Sudarsono. Character Building Membentuk Watak. Jakarta: 
$136 \frac{\text { Jurnal AL-AFKAR }}{\text { Vol. II, No. II, Oktober } 2013}$

PT Elex Media Komputindo, 2002

Tim Penyusun Kamus Pusat Pembinaan dan Pengembangan Bahasa.

Kamus Besar Bahasa Indonesia. Ed.2, Cet.3. Jakarta: Balai Pustaka, 1994

UU Sisdiknas No. 20 Tahun 2003. Bandung: Fokusmedia,2003 